\title{
MERLEAU-PONTY JAKO MILNÍK DUFRENNOVA MYŠLENÍ
}

\author{
FELIX BORECKÝ \\ Katedra filozofie, Filozofická fakulta, Univerzita Palackého v Olomouci \\ E-mail: felix.borecky@seznam.cz
}

\begin{abstract}
Merleau-Ponty as Milestone of Dufrenne's Thought
The aim of this article is to outline the relationship between the ideas of Mikel Dufrenne and those of Maurice Merleau-Ponty. Unlike Dufrenne's work on this distinguished thinker, a Czech translation of which follows in this issue, the author tries to bring out not only the connections (such as their philosophies of perception and their gradual inclination to the philosophy of nature), but differences as well. Considering Dufrenne's work as a whole, the author focuses on concepts that are exclusively Dufrenne's, irreducible to the philosophy of Merleau-Ponty, in particular Dufrenne's three-level theory of knowledge, conception of the a priori, and the superior status of aesthetic experience over other kinds of experience.
\end{abstract}

Keywords: M. Dufrenne; M. Merleau-Ponty; primacy of perception; philosophy of Nature; three-level theory of knowledge; aesthetic experience

Patrně žádný jiný filosof neměl na Mikela Dufrenna tak velký vliv jako jeho o dva roky starší spolužák z École Normale Supérieure Maurice Merleau-Ponty. Bylo by však zploštující označit Dufrennovo myšlení za výhradně merleau-pontyovské. Studii „Maurice Merleau-Ponty", jež vyšla poprvé v Les études philosophiques roku 1962 krátce po smrti obdivovaného myslitele a již si zde nyní může přečíst i český čtenář, lze sice charakterizovat jako vyznání obdivu a přináležitosti $\mathrm{k}$ Merleau-Pontyho východiskům, Dufrenne je však v první řadě samostatný myslitel a jinými filosofiemi a filosofy se zabývá především $\mathrm{z}$ toho důvodu, že v nich spatřuje možnost projasnit svou vlastní filosoficko-estetickou koncepci. ${ }^{1}$

Tento př́stup se odráží jak v textech, jež prezentuje jako vlastní originální př́spěvky a v nichž se východisky svých předchůdců zabývá poměrně málo, a především nikterak důkladně (od Phénoménologie de lexpérience esthétique přes La notion d’a priori, Le poétique, až po pozdní L'inventaire des a priori či L'oeil et l'oreille), projevuje se však i ve studiích věnovaných konkrétním myslitelům, které soustavně publikoval mezi lety 1948 a 1963 v prestižních filosofických časopisech, jako byly např́ílad Esprit, Revue de la métaphysique et de morale, Combat či Les études philosophiques. V roce 1966 je pak souborně otiskl v knize Jalons. Ani v tomto prrípadě nejde o sekundární literaturu v přísném slova

1 M. Dufrenne, „Maurice Merleau-Ponty“, Les Études philosophiques, roč. 17, leden-březen 1962, č. 1, s. 81-92; M. Dufrenne, Maurice Merleau-Ponty, in: M. Dufrenne, Jalons, Martinus Nijhoff, La Haye 1966, s. 208-221. 
smyslu, ale spíše o představení toho, co se mu na autorech, jako jsou Spinoza, Kant, Hegel, Heidegger, Wittgenstein, Bachelard či Sartre, hodí, v čem jsou tito autoři pro něj určující a v čem ho ovlivnili. ${ }^{2}$ Jsou pro něj, vyjdeme-li z názvu knihy, v první řadě „milníky“ (francouzsky jalons) jeho vlastního směřování, a proto je nejcennější číst prríslušné studie na pozadí jeho vlastní filosofie a estetiky.

Ve studii „Maurice Merleau-Ponty“, jež celý soubor Jalons uzavírá, Dufrenne typicky ve svém stylu vyzdvihuje na Merleau-Pontyho filosofii ty momenty, jež jsou ve shodě s jeho vlastní esteticko-filosofickou koncepcí. Oceňuje Merleau-Pontyho kritické vymezení se vůči Husserlovu transcendentálnímu idealismu, Heideggerově filosofii bytí, souhlasí s jeho spíše pozitivním hodnocením Sartrovy filosofie svobody a přijímá i jeho náhled na využitelnost hegelovské dialektiky. ${ }^{3}$ Hlavní jádro studie pak spočívá v interpretaci Merleau-Pontyho filosofie, již vykládá v intencích plně vyhovujících jeho vlastnímu projektu. Chápe ji nejen jako filosofii vnímání, ale i jako filosofii Přírody. Intencionální vztah mezi vnímaným a vnímajícím, jenž má ve své originární podobě stejný tělesný základ (le fondement), by měl být zaručen ideou Př́rody. Nezpředmětnitelnou Přírodu považuje za monistický kořen, z něhož se rodí a vyvstává jakákoliv intencionální korelace mezi subjektem a objektem. Domnívá se, že Merleau-Pontyho filosofii vnímání je zajímavější spojit právě s filosofií Přírody než s Heideggerem a jeho „stále unikavější ontologií“" ${ }^{4}$ V textu přímo píše, že Merleau-Ponty „nestihl spojit ideu Př́rody s ideou základu jakožto a priori všech a priori a u samého kořene monismu odhalit zrod dualismu a proměnu člověka a světa“. 5 Jinými slovy, Dufrenne Merleau-Pontymu vytýká, že se nevydal cestou, kterou se vydal on sám, a v předložené studii jej navrhuje interpretovat tímto směrem. Dodejme ještě, že v době, kdy Dufrenne text o Merleau-Pontym psal, pracoval zároveň na knize Le poétique, již publikoval o rok později a dospěl v ní k pevnějšímu spojení filosofie vnímání a filosofie Př́rody. ${ }^{6}$

Tamtéž (celá kniha).

3 Domníváme se ovšem, že v Dufrennově myšlení je hegelianismus př́itomen víc, než si byl autor sám ochoten přiznat. Viz níže rozbor Dufrennovy teorie poznání, v níž autor rozlišuje tř̌i základní roviny prezence, reprezentace a citu. Cit, jejž vztahuje výhradně na estetickou zkušenost, lze vykládat jako jistou variantu Hegelova Aufhebung, tedy jako syntézu, v níž teze (resp. prezence) je poučená antitezí (resp. reprezentací) a umožňuje tak poznání hlubokých, tzv. apriorních pravd. Na rozdíl od Hegela však Dufrenne chápe poznání estetických apriorních pravd jako vždy omezené na určitý jejich výčet s ohledem na konkrétní dějinnou a existenciální situaci člověka. K Merleau-Pontyho vztahu k dialektice, a to nejen té hegelovské, srov. M. Merleau-Ponty, Viditelné a neviditelné, OIKOYMENH, Praha 2004, kap. „Tázání a dialektika“; Résumés de cours, Gallimard, Paris 1968, shrnutí z let 1955-1956, „La philosophie dialectique“ a „Textes et commentaire sur la dialectique“; český překlad Př́roda, řeč, dějinnost, filosofie. Shrnutí přednášek z Collège de France (1952-1960), OIKOYMENH, Praha 2018 (v tisku); rozbor Merleau-Pontyho nepublikovaných podkladů k přednáškám o dialektice podává $\mathrm{M}$. Larison, L'Etre en forme. Dialectique et phénoménologie dans la dernière philosophie de Merleau-Ponty, Paris, Vrin 2016.

4 M. Dufrenne, Maurice Merleau-Ponty, Acta Universitatis Carolinae. Philosophica et Historica. Studia Aesthetica, č. 1, 2018, s. 109.

5 Tamtéž.

6 M. Dufrenne, Le poétique, Presses Universitaires de France, Paris 1963. V první ucelené monografii, která o díle Mikela Dufrenna vyšla, pracuje Frédéric Jacquet s tezí, že Dufrenne vybudoval v rámci fenomenologické antropologie perspektivu filosofie zrození (philosophie de la naissance), jíž dovršuje do důsledků Merleau-Pontyho filosofii tělesnosti. Jednotlivé existenciály pak Jacquet vykládá nikoli ze smrti (bytí k smrti), ale právě ze zrození a je přesvědčen, že „filosofie zrození“ může proti filosofii konečnosti lidské existence nastolit odlišnou a př́esvědčivější perspektivu. F. Jacquet, Naître au monde. Essai sur la philosophie de Mikel Dufrenne, Ed. Mimésis, Paris 2014. 
Vzhledem k tomu, že se čtenář studie musí připravit na Dufrennův specifický styl vyznačující se jistým kolísáním mezi tím, co jsou náhledy Merleau-Pontyho a co jeho vlastní, pokusíme se v následujícím úvodu načrtnout nejzákladnější kontury toho, v čem se Dufrenne od Merleau-Pontyho zásadně vzdaluje, tedy především jeho tříúrovňovou teorii poznání, vyzdvihování estetična nad ostatní oblasti, koncepci a priori a Př́rody. Začněme ovšem společným východiskem obou autorů.

\section{Filosofie prezence ${ }^{7}$}

V návaznosti na perspektivu, kterou vypracoval a filosoficky zdůvodnil Merleau-Ponty, považuje Dufrenne za východisko veškerého opravdového poznání bezprostředně žité tělesné vnímání, v němž se subjekt a objekt, člověk a svět, vzájemně prostupují a mají stejný tělesný základ (fondement). V této původní prezenci jsou subjekt i objekt ještě na stejné úrovni, kterou by jakékoliv subjekt-objektové oddělování mělo vždy zohledňovat, aby nebyla jejich původnější př́buznost abstrahována od společného zdroje. Motivace této filosofie je samozřejmě fenomenologická: záleží jí na tom, aby veškeré poznatky, $\mathrm{k}$ nimž docházíme, byly uváděny do souvislosti s bezprostředním vnímáním věcí a světa, ve kterém žijeme, a nikoli abychom spoléhali na již převzaté objektivizované významy, jež odhlížejí od původních žitých vazeb. Merleau-Ponty a Dufrenne však věří, že nalézají fenomenologicky věrnější půdu než jeho němečtí předchůdci. Husserlův transcendentální idealismus i Heideggerova filosofie bytí předpokládají podle nich jistý nepřítomný, a tedy stále do určité míry metafyzický princip, kdežto filosofie prezence nehledá svůj základ nikde mimo člověka a mimo svět, nýbrž právě v jejich intencionálním střetnutí - ve vnímání. ${ }^{8}$ Fenomenologicky důsledné vnímání tak musí podle filosofie prezence být otevřené nejen ze strany subjektu vůči objektu, ale i objektu vůči subjektu, aniž by jeden převládl nad druhým; mají si být rovnocenní. Této rovnováhy může být dosaženo jedině tehdy, bude-li vnímání neustále čerpat ze svého původního zakořenění v tělesném základu. Merleau-Ponty s Dufrennem věrí, že filosofie prezence se dokáže adekvátněji než tradiční filosofické projekty vyvarovat jak nástrah subjektivismu (idealismu, intelektualismu), u něhož převládá subjekt, tak objektivismu (realismu, naturalismu), u něhož převládá objekt.

Třebaže výchozí myšlenku Merleau-Pontyho filosofie Dufrenne přejímá, pracuje s ní ve své obecné trojstupňové teorii poznání přísněji, snad až rigidněji. U Merleau-Pontyho má být primát vnímání zohledněn při řešení všech filosofických problémů. Veškeré lidské poznávání má být popsáno podle vnímání a člověk by se měl na všech úrovních poznání naučit, řečeno s názvem stěžejní české monografie o Merleau-Pontym od Jakuba Čapka, „myslet podle vnímání“. Naproti tomu Dufrenne považuje takový cíl přísně vzato za splnitelný jen v oblasti estetické zkušenosti. Pro oblast teoretického poznání vědy a filosofie by měl primát vnímání sice rovněž platit za ideál, ale považuje jej za fakticky

7 Termíny „filosofie prezence“ a „filosofie vnímání“ používáme synonymně. Pojem prezence je však v rámci Dufrennova myšlení instruktivnější při jeho odlišování prezence a reprezentace.

8 „Prvotní - řekněme transcendentální - je tedy skutečně jevení, vyvstávání smyslu v prezenci." M. Dufrenne, Maurice Merleau-Ponty, viz výše, s. 104; Srov. M. Dufrenne, Intentionnalité et esthétique, in: M. Dufrenne, Esthétique et philosophie I, Klincksieck, Paris 1988, s. 53-54. 
nesplnitelný. ${ }^{9}$ Pojmové abstrakce mají sklon až př́liš rychle odhlížet od původní prezence a poskytují pouze omezené poznání konstruované lidskou myslí, a nikoli autentické intencionální korelace mezi člověkem a světem.

Jakub Čapek ve zmíněné monografii rozlišuje celkem tř̌i významy „primátu vnímání“. ${ }^{10}$ Načrtněme zde ve stručnosti jejich základní vymezení, které nám umožní lépe a odstíněněji pochopit, jak primát vnímání chápat, a to nejen u Merleau-Pontyho, ale i u Dufrenna. První význam Čapek označuje za „genealogický“. Podle něj je vnímání prvním střetem se skutečností a z něho vycházejí a rozvíjejí se další způsoby poznávání, jako jsou řeč či racionální úkony. Ty však následují po původním vnímání, na němž jsou závislé a bez něhož pracují zavádějícím způsobem. Druhý „fundační“ význam popisuje vnímání jako základ veškerých poznávacích aktů, a to i těch, u nichž člověk nedokáže rekonstruovat reálnou časovou genezi a jejich původní vázanost na místo a čas. Tedy i obecniny jsou podle tohoto významu vposled fundovány ve vnímání a vnímání je jejich základem. Konečně třetí význam primátu vnímání označuje Čapek za „modelovýc. Podle něj je vnímání vzorem pro všechny jiné roviny poznání, jako jsou obecniny, řeč, rozum, vztah k druhým. Podle tohoto třetího vymezení by se pak tedy jakékoliv uvažování v pojmech mělo podřídit primátu vnímání, tedy i veškerá filosofie i věda. V̌̌echny tyto tři významy, jak Čapek dále uvádí, se u Merleau-Pontyho objevují a je třeba dbát na to, která $\mathrm{z}$ variant je $\mathrm{v}$ té které pasáži jeho díla zdůrazňována, a tomu přizpůsobit výklad. Většina interpretů Merleau-Pontyho si toto úskalí podle Čapka neuvědomovala. ${ }^{11}$

Čapkovo trojí rozlišení primátu vnímání by se dalo nalézt i v Dufrennově filosofii, a tak i interpretovi tohoto autora by mohlo být dobrou pomůckou, jestliže by při výkladu zohlednil, který z významů má v tom kterém př́padě na mysli. Dufrenne chápe primát vnímání nejen genealogicky jako první faktický střet se světem co do času (v dětství, resp. v prehistorii lidstva), ale i jako prvotní a původní zdroj poznání, z něhož pochází jak subjekt, tak objekt, tedy vlastní fenomenologická půda veškerého zjevování. Vnímání je tudíž zároveň i původní půda či základ (fondement), z níž se jak člověk, tak svět, jak subjekt, tak objekt načerpávají. ${ }^{12}$ U Dufrenna se ovšem objevuje i třetí význam primátu vnímání, kterého si Čapek všímá, tj. vnímání jako vzor neboli model, podle něhož by se mělo řídit veškeré poznávání, jež chce být autentické a důsledně fenomenologické. Takovým poznáním je ale podle Dufrenna výhradně poznání estetické. V tom se objevuje patrně největší rozdíl oproti Merleau-Pontymu, jenž je k uchopování teoretických (a obecně řečeno sedimentovaných) významů mimo estetickou zkušenost přívětivější a nespatřuje $\mathrm{v}$ nich jen odcizující odklon od bezprostředně vnímaného světa. Merleau-

9 „Et le discours le plus abstrait ne cesse de se fonder sur cette pré-connaissance du monde engagée dans notre présence au monde“ [I ten nejabstraktnější diskurs se neustále zakládá na předchůdném poznání světa, které je spjaté s naší prezencí ve světě]. M. Dufrenne, L'inventaire des a priori. Recherche de l'originaire, Christian Bourgeois Editeur, Paris 1981, s. 287.

10 J. Čapek, Maurice Merleau-Ponty. Myslet podle vnímání, Filosofia, Praha 2012, s. 13-16 a 45-50.

11 Tamtéž, s. 14-15. Viz Čapkův výčet sekundární literatury v pozn. 5, s. 15.

12 Srov. „[L]'homme est de connivence avec le monde, et [...] il peut trouver dans cette intimité une occasion déchapper un moment à la pression des pouvoirs ou aux contraintes de la culture, de goûter la saveur du sensible, bref de se ressourcer" [člověk je ve spřízněnosti se světem a v této důvěrnosti může nalézt př́ležitost na chvíli uniknout nátlaku sil a omezení kultury, okusit chut’ smyslového pocitování, zkrátka načerpat se]. M. Dufrenne, L'inventaire des a priori, viz výše, s. 15. 
-Ponty konzistentně zastává přesvědčení, že „způsob př́istupu k bytí, který existuje ve vnímání, je přítomen všude“, na všech úrovních poznání. ${ }^{13}$

Popišme nyní ve stručnosti Dufrennovu obecnou teorii poznání, v níž rozlišuje tři základní roviny: prezence, reprezentace a cit. Ta nám může být vhodnou pomůckou k lepšímu pochopení vztahu mezi Dufrennem a Merleau-Pontym.

\section{Primát vnímání a třiúrovňová teorie poznání}

1. Rovina prezence je oním vyrovnaným tělesným poznáním, kde se subjekt a objekt vzájemně prostupují a udržují v tomto vztahu „dojem plnosti“ (l’impression de plénitude). Pro Dufrenna je tato rovina poznání jakýmsi ideálem, za nímž se nostalgicky ohlíží. Takového bezprostředního zakoušení jsou podle Dufrenna schopny pouze děti a přírodní národy. Dospělý moderní člověk tuto schopnost ztratil pod nánosem př́liš rozvinutého pojmového myšlení (reprezentací) a ohlašují se mu jen ve výjimečných a prchavých okamžicích, jako je například tíha vzduchu, jež předchází bouřce, či intonace hlasu naznačující vztek. Vnímání v prezenci Dufrenne chápe jako čistě naivní, před-vědomou zkušenost a v tom spočívá i její omezení. Subjekt a objekt se zde poznávají, ale nerozpoznávají se. K původnímu vnímání se můžeme dostat vždy až zprostř̌edkovaně skrze reflexi; v ní se ale mění i její původní význam, který ještě nelze oddělit od znaku a přidělit mu jasný denotát. Význam zde vyvstává z původní tělesné jednoty jakožto výzva, již potvrzuje bezprostřední před-vědomé chování.

2. Nejčastěji podle Dufrenna žijeme v reprezentacích. Zatímco na úrovni prezence byl význam od znaku, tedy svého nositele, neodlišitelný a byl tělesně plně, leč naivně prožívaný, na úrovni reprezentace se obě složky od sebe oddělují. Z původní prezence se stává re-prezentace, která je složena ze tří složek. Má jasný zjev (apparence, signifiant) tak, aby ji bylo možno podřadit pod pojmově vyčerpatelný význam (signifié), který vymezí způsob, jak poznat věc (chose). Nejčastěji žijeme právě v reprezentacích, kde využíváme co nejjednoznačnější významy, jimž potřebujeme rozumět bez ambivalencí, abychom je mohli snadno přiřadit $\mathrm{k}$ náležitým kontextům a shodnout se na nich s druhými. Všechny naše prakticky a teoreticky zaměřené činnosti mají tento charakter. Dufrenne zdo̊razňuje, že reprezentace jsou sice přesné, ale odvádějí nás od přirozených vztahů vnímaného světa. Jsou sice naprosto nepostradatelné pro život člověka, ale je velkým ochuzením, spoléhá-li pouze na ně. Podle Dufrenna k tomu mají sklon především lidé v moderních vyspělých společnostech. Ztrácejí kontakt se smyslovým světem, bez něhož mohou obtížně nalézt celkovou souvislost a orientaci ve světě.

3. Nejvyšším typem poznání je pro Dufrenna rovina citu, který se uskutečňuje v estetické zkušenosti. Zde se vnímající subjekt vrací k žitým významům původní prezence, a přitom je poučený reprezentacemi praktického a teoretického života. V citu dochází k paradoxnímu intencionálnímu pohybu přilnutí a odstupu mezi subjektem a objek-

13 M. Merleau-Ponty, Le monde sensible et le monde de l'expression. Cours au Collège de France. Notes, 1953, MetisPresses, Genève 2011, s. 45; citováno v J. Halák, ,Vnímání je již vyjadřování. Merleau-Pontyho první přednášky na Collège de France, Reflexe 52, s. 111-135. 
tem. Dufrenne také hovoří o sympatické reflexi. Sympatické přilnutí přibližuje subjekt k objektu tak, aby mohl zakoušet smyslově pocitované aspekty zkušenosti. Reflexe jej naopak vede k zaujetí odstupu, díky kterému je schopen zahlédnout vzájemnou souvislost roviny prezence a reprezentace. Paradoxní pohyb sympatické reflexe se uskutečňuje výhradně v estetické zkušenosti a je Dufrennovou vlastní verzí obhajující kantovskou koncepci bezzájmového zalíbení (nezainteresovanosti).

\section{Estetika, estetismus, a priori, Př́roda}

Třiúrovňová teorie poznání provází celé Dufrennovo dílo od Phénoménologie de l’expérience esthétique až k pozdní L’inventaire des a priori. ${ }^{14} \mathrm{Z}$ jejich výměrů celkem zřetelně vyplývá, že Dufrenne privileguje estetično a estetickou zkušenost na úkor ostatních typů vztahování se ke světu. Je to dáno především Dufrennovým celkově negativním náhledem na reprezentace. Třebaže na některých místech svého díla Dufrenne připouští, že by i reprezentace měly být uváděny do souvislosti s vnímaným světem a používány v souladu s vnímáním (tedy po vzoru Čapkova modelového významu „primátu vnímáni“'), povětšinou je chápe jako objektivizované významy, které nás od vnímaného světa oddalují. Dufrennovi lze jistě vytknout, že je s reprezentacemi až příliš brzy hotov a že za plně autentické je považuje jen tehdy, stanou-li se součástí estetické reflexe. Proto ani jakákoliv teorie, at’ věda, nebo filosofie, není podle něj schopna fenomenologicky věrně obsáhnout všechny aspekty zkušenosti, protože je prováděna výlučně v médiu reprezentací, a unikají jí tak smyslové, imaginativní a citové, souhrnně řečeno aishetické, vrstvy vnímání. To platí i pro filosofii, která reprezentace sice dokáže reflektovat, ale její reflexe je výhradně teoretická a jako taková setrvává v reprezentacích.

K původnímu vnímání se můžeme podle Dufrenna dostat jedině přes estetickou zkušenost. Nejde ovšem o „návrat“ k originární prezenci, ale o poučený návrat. Přichylujeme se v ní k původnímu smyslově pocitovanému světu, ale zohledňujeme i reprezentace, jež jsme poznali v našem praktickém a teoretickém životě. Estetická zkušenost je zkušenost reflexivní, v níž je vnímání smyslově pocitovaného světa uvedeno do souvislosti s prakticko-teoretickým životem. Estetický cit je prezence poučená reprezentacemi, a je tedy jakousi vyšší syntézou obou předchozích rovin, v níž může dojít k pravému autentickému poznání světa a sebe sama. ${ }^{15}$

Na rozdíl od Dufrenna není privilegování estetična u Merleau-Pontyho tak vyostřené a oceňuje stejně prvořadý význam filosofie: „Opravdovou filosofií je,“ jak píše v předmluvě k Fenomenologii vnímání, „naučit se opět vidět svět."16 Estetickou zkušenost neklade výše nebo níže než zkušenost filosofickou, ale považuje je obě za schopné sdělovat hlubo-

14 Dufrennova teorie poznání není přísně vzato „jen“ teorií poznání, ale podobně jako u Merleau-Pontyho je i způsobem bytí. Noetika (epistemologie) zde přechází do ontologie, v níž člověk a svět jsou chápáni jako neoddělitelné součásti struktury „bytí ve světě“. Pocitující člověk je vždy determinován situací, na niž reaguje, stejně jako pocitovaný svět reaguje na člověka.

15 Viz výše, srov. pozn. 3, v níž jsme upozornili na jisté rysy hegelovské Aufhebung v Dufrennově koncepci estetické zkušenosti.

16 M. Merleau-Ponty, Fenomenologie vnímání, OIKOYMENH, Praha 2013, s. 26. 
ké významy světa. ${ }^{17}$ Filosofie je „podobně pracná jako Balzakovo dílo, jako dílo Prousta, Valéryho či Cézanna. Vyznačuje se tímtéž typem pozornosti a údivu, tímtéž nárokem na vědomí, toutéž vưlí uchopit smysl světa či dějin ve stavu zrodu“ "18 Merleau-Ponty nevidí jako překážku, že se filosofie pohybuje v pojmech, kdežto umění využívá aisthetické aspekty, důležité je, aby obě poskytovaly „vodítka“ k vnímanému světu. Chce vypracovat filosofii podle vnímání a umění chápe jako vhodný př́klad, na němž se můžeme poučit o „myšlení podle vnímání “ ${ }^{19}$ Chce, jak jsme výše uvedli, myslet veškerou skutečnost podle toho, jak je nám původně otevřena ve vnímání, a ve srovnání s Dufrennem podává mnohem detailnější rozbory ne-estetických fenoménů, které Dufrenne označuje za „reprezentace“.

Dufrenna lze označit za obhájce estetismu, tedy náhledu, že nejucelenějšího poznání dosahujeme v estetické zkušenosti, zatímco všechny ostatní typy zkušeností (žitá prezence, praktická, teoretická, filosofická zkušenost) jsou vždy něčím limitované. Estetická zkušenost je pravým cognitio sensitiva, smyslovým poznáním, kdy v jednotlivé, smyslově pocitované jednotlivině nalézáme obecně pravdivé vyjádření o bytí ve světě. Podle Dufrenna bude vždy hlubší a fenomenologicky pravdivější ta zkušenost, která zohledňuje žité aspekty zkušenosti a neuchyluje se k jejich abstrahování do pojmových reprezentací. Musí tudíž být sensitiva. Smyslové pocitování, tělesnost, imaginace, city, tedy ty aspekty lidského poznávání, které Řekové označovali jako aisthésis, jsou podle Dufrenna nejvlastnějším vodítkem $\mathrm{k}$ pravému poznání a jedině $\mathrm{z}$ něj a na něm je možné učinit takovou zkušenost. V upevnění tohoto náhledu mu jistě pomohly filosofické kategorie a celková filosofická perspektiva vypracovaná Merleau-Pontym.

Zároveň s tím Dufrenne ovšem zůstává věrný tradici estetiky nezainteresovanosti (estetického postoje). Estetická zkušenost je podle něj přirozeným vzájemným otevřením člověka a světa, v němž se uskutečňuje sympatická reflexe. Subjekt zde k objektu citově přilne, a přitom si od něj zároveň udržuje odstup. Pouze v tomto typu intencionálního vztahu mohou subjekt a objekt dosáhnout vzájemné rovnocennosti. ${ }^{20}$ Jen díky estetickému vztahování se ke světu může člověk zakoušet pravdivá svědectví o bytí ve světě. Jinými slovy, estetická zkušenost je nejen smyslově pocitovaná (sensitiva), ale je také zdrojem poznání (cognitio), a to dokonce poznání nejhlubšího.

Tím se dostáváme $\mathrm{k}$ Dufrennově patrně nejoriginálnější myšlence, a sice $\mathrm{k}$ jeho koncepci a priori. A priori chápe jako jakési základní konstanty „bytí ve světě“, které vystihují

17 „[V] tomto smyslu může být př́iběh, který někdo vypráví, stejně ,hlubokýc jako filosofické pojednání, může rovněž tak sdělovat významy světa, " tamtéž. V Oku a duchu Merleau-Ponty dokonce tvrdí, že filosofie by se měla učit od malî́ství, jak mluvit o onom „ještě němém“ světě, který zůstává mimo reprezentace, a jak jej nechávat promlouvat. Zde se Dufrennovi formulačně velmi přibližuje. Oba navíc jako vzorového malíře, který dokáže nechávat vidět, nejčastěji uvádějí Paula Cézanna. M. Merleau-Ponty, Oko a duch, in: M. Merleau-Ponty, Oko a duch a jiné eseje, Obelisk, Praha 1971, s. 7-34, př́p. M. Merleau-Ponty, Cézannovo pochybování, in: tamtéž, s. 35-51.

18 M. Merleau-Ponty, Fenomenologie vnímání, viz výše, s. 26. Srov. např. Předmluva ke Znakům, v níž porovnává filosofii a umění ve stejném duchu. M. Merleau-Ponty, Smysl filosofického tázání. Dva texty k Viditelnému a neviditelnému, Filosofia, Praha 2016, str. 22.

19 Tak jako např. Cézanne „myslí malbou“ („pense en peinture“), M. Merleau-Ponty, Oko a duch, viz výše, s. 23.

20 Např́klad ve studii „Intencionalita a estetika“ dává tuto subjekt-objektovou rovnocennost uskutečňující se v estetické zkušenosti do souvislosti s fenomenologickou redukcí: „[L]’expérience esthétique accomplit la réducton phénoménologique“. M. Dufrenne, Intentionnalité et esthétique, viz výše, s. 55. Estetická zkušenost je pro Dufrenna přirozeným uskutečněním fenomenologické redukce, jíž je schopen i člověk, který není filosofem. 
to, co je pro vztah mezi člověkem a světem, subjektem a objektem, hlubším způsobem pravdivé. Jejich odhalení není př́imo závislé na empirickém řádu, tj. na tom, co člověk zažil a čím je fakticky zkušenostně obklopen, nýbrž jde o všeobecně platné vzorce lidství, jež jsou obsaženy ve struktuře „bytí ve světě“ a zakládají ji. A priori předcházejí subjektu i objektu a umožňují, aby se subjekt i objekt dostaly do společné prŕbuznosti (affinité) a mohly navázat autentickou komunikaci. Pokud se tyto apriorní vazby mezi člověkem a světem odhalí, jsou podle Dufrenna dány bezprostředně a ihned. Člověk si k nim nemůže vydobýt cestu žádným učením či cvičením vycházejícím z empirických, tj. aposteriorních zkušeností.

Posledním garantem apriorních vztahů mezi člověkem a světem neboli $a$ priori všech a priori je podle Dufrenna Př́roda. ${ }^{21}$ Chápe ji, jsa inspirován Spinozou a Schellingem, jako limitní ideu, jež se vzpírá jakémukoliv uchopení a artikulaci. Příroda je Nature naturante, dává zrod veškerému světu (nature naturée), at žitému, nebo myšlenému, a zaručuje apriorní př́buzenství mezi subjektem a objektem (la parenté de l'a priori), jež předchází jakýmkoliv empirickým významům. Za prríhodných okolností, kdy subjekt přilne k objektu jako k objektu estetickému a intencionálně se k němu vztáhne estetickým citem, může dojít k rozezvučení hloubek obou členů vztahu a odhalení a priori. Je to právě Příroda, která a priori vkládá do tohoto vztahu a podněcuje v člověku pocit fundamentální příbuznosti (affinité) nebo přímo konsubstanciality (consubstantialité) se světem.

Jak jsme naznačili již na začátku tohoto úvodu, ve studii „Maurice Merleau-Ponty“ se Dufrenne svého inspirátora snaží interpretovat jako filosofa Přírody. Podle Fréderika Jacqueta, významného interpreta Dufrennova díla, je to ve skutečnosti až sám Dufrenne, který dovršil filosofii tělesnosti a spojil ji s filosofií Př́rody. ${ }^{22}$ Merleau-Pontymu se podle Jacqueta, jenž ve svém výkladu hojně čerpá z Dufrennovy zde přeložené studie, nepodařilo zapustit subjekt do primordiální fysis, jež je „univerzální formou syrového bytí, nedokázal určit princip fenomenologické diference mezi tělem a světem, který se prostřednictvím těla fenomenalizuje, a zůstal tak pouze na prahu kosmologie. ${ }^{23}$ Podle Jacqueta tedy až Dufrenne přesvědčivě propojil Merleau-Pontyho filosofii s filosofií Přírody, s kosmologií, která neredukuje člověka na pouhou část Přírody, ale dokáže lidské vztahování se ke světu koncipovat z primordiální struktury jevení - nikoli z projektu bytí k smrti, nýbrž z perspektivy zrození do světa.

S takovou interpretací se dá jistě polemizovat. ${ }^{24}$ Díky překladu studie „Maurice Merleau-Ponty “ má každopádně nyní i český čtenář možnost zvážit, zda jsou Dufrennovy argumenty akceptovatelné, či nikoliv.

21 Ve Phénoménologie de l’expérience esthétique používá Dufrenne ještě pojem bytí, od 60. let se uchyluje $\mathrm{k}$ Schellingem inspirovanému pojmu Příroda.

22 F. Jacquet, Naître au monde. Essai sur la philosophie de Mikel Dufrenne, viz výše, s. 30.

23 „Merleau-Ponty demeure, au seuil d'une cosmologie', manque l'inscription du sujet de la corrélation au sein de la physis primordiale, irréductible au sensible, forme universelle de lêtre brut' et ne parvient pas à fixer le principe de la différence phénoménologique, celle du corps, à légard du monde qui se phénoménalise par l'intermédiaire de ce corps.“ Tamtéž, s. 30-31.

24 Bylo by jistě třeba využít Merleau-Pontyho vlastní náhledy na problém Přírody. Zejména jeho rukopisy z Collège, na níž o tomto tématu tři roky přednášel. Srov. M. Merleau-Ponty, La Nature. Notes. Cours du Collège de France, Seuil, Paris 1995. 


\section{Poděkování}

Tato studie je výsledkem badatelské činnosti podporované Grantovou agenturou České republiky v rámci grantu GA ČR 16-17984Y Kořeny Merleau-Pontyho převrácení objektivistického paradigmatu $v$ přednáškách $\mathrm{z}$ Collège de France řešeného na Filozofické fakultě Univerzity Palackého v Olomouci.

\section{LITERATURA}

Čapek, J., Maurice Merleau-Ponty. Myslet podle vnímání, Filosofia, Praha 2012.

Dufrenne, M., Intentionnalité et esthétique, in: Dufrenne, M., Esthétique et philosophie I, Klincksieck, Paris 1988, s. 53-61.

---, Le poétique, Presses Universitaires de France, Paris 1963.

---, L'inventaire des a priori. Recherche de l'originaire, Christian Bourgeois Editeur, Paris 1981.

---, Jalons, Martinus Nijhoff, La Haye 1966.

---, Maurice Merleau-Ponty, Les Études philosophiques, roč. 17, leden-březen 1962, č. 1, s. 81-92.

---, Maurice Merleau-Ponty, Acta Universitatis Carolinae. Philosophica et Historica. Studia Aesthetica, č. 1, 2018, s. 101-109.

---, Phénoménologie de l'expérience esthétique, 2 sv., Presses Universitaires de France, Paris 1967.

Halák, J., „Vnímání je již vyjadřování. Merleau-Pontyho první přednášky na Collège de France, Reflexe 52, s. 111-135.

Jacquet, F., Naître au monde. Essai sur la philosophie de Mikel Dufrenne, Ed. Mimésis, Paris 2014.

Larison, M., L'Etre en forme. Dialectique et phénoménologie dans la dernière philosophie de Merleau-Ponty, Paris, Vrin 2016.

Merleau-Ponty, M., Cézannovo pochybování, in: Merleau-Ponty, M., Oko a duch a jiné eseje, Obelisk, Praha 1971, s. 35-51.

---, Fenomenologie vnímání, OIKOYMENH, Praha 2013.

---, La Nature. Notes. Cours du Collège de France, Seuil, Paris 1995.

,--- Le monde sensible et le monde de l'expression. Cours au Collège de France. Notes, 1953, MetisPresses, Genève 2011.

---, Oko a duch, in: Merleau-Ponty, M., Oko a duch a jiné eseje, Obelisk, Praha 1971, s. 7-34.

---, Př́roda, řeč, dějinnost, filosofie. Shrnutí přednášek z Collège de France (1952-1960), OIKOYMENH, Praha 2018 (v tisku).

---, Résumés de cours. Collège de France (1952-1960), Gallimard, Paris 1968.

---, Smysl filosofického tázání. Dva texty k Viditelnému a neviditelnému, Filosofia, Praha 2016.

---, Viditelné a neviditelné, OIKOYMENH, Praha 2004. 